\title{
Negotiating Femininities: Petites Filles and Public Parks in Nineteenth-Century Paris
}

\author{
Sinéad Helena Furlong
}

Cet essai étudie l'inscription textuelle et visuelle de la petite fille comme prototype de la mère bourgeoise, comme une petite femme qui apprend à se conformer à la construction d'une féminité " honnête " dans la France du dix-neuvième siècle. Les petites filles apprenaient à négocier les constructions contemporaines de genre en observant et imitant les modelles du comportement, de l'habillement et de la parole. La réalité de l'intérieur domestique est extériorisée dans le parc public, où les enfants observent les adultes et apprennent à se comporter comme eux, jouant, selon les termes de Baudelaire, la comédie donnée à domicile par leurs parents mais en apprenant aussi les façons de subvertir les règles de la comédie domestique bourgeoise par le biais de féminités alternatives et parfois perturbantes.

This essay considers the textual and visual inscription of the petite fille as prototype of the bourgeois mother, a little woman learning how to conform to the construct of "honest" femininity, in mid- to late-nineteenth-century France. Little girls learned to negotiate contemporary gender constructs by observing and emulating female models of behaviour, dress and speech. In the domestic interior, available female models (mother, sister, other female relative, servant) were defined in terms of their relation to the little girl. However, once out of the home, myriad - and often ambiguous - models of femininity were to be found, in spite of efforts on the part of anxious mothers and fathers to exclude examples of "dishonest" femininity from the gaze of the growing child in the process of her socialisation into the Symbolic order of clearly defined gender concepts. ${ }^{i}$ In nineteenth-century Paris, heroines of popular literature and the stage were courtesans and prostitutes, as were the most fashionable women to whom society columns and - ironically - fashion journals with their largely middle-class readership drew attention. In the public space, the issue of the paradoxical emulation and rejection of the demi-monde by the fashionable yet "honest" bourgeois wife was a source of concern for those anxious to sustain existing gender definitions. In midnineteenth-century Paris, Haussmann's administration created a network of public parks, spaces to which children were brought, dressed in their finery, and in which children observed their elders, interacted with one another, participating wittingly or not in the contemporary cult of spectacle and display (see Furlong 2001). As this essay will demonstrate, in the park the domestic interior is exteriorised, children watch their elders and learn how to behave as adults, playing out, in Baudelaire's terms, the comédie donnée à domicile par leurs parents (719), but also, 
importantly, learning ways in which to subvert the rules of the bourgeois domestic comedy, through alternative and occasionally disruptive femininities.

The public park was a paradoxical, problematic space. Presented by travel guide-writers and fashion journalists, moralists and ministers as safe haven for mothers and babies, as prime site for the parading of family values, the public park was also inevitably the site of the spectacle and display associated with the demimonde, and thus that which bourgeois society both feared and desired in equal measure. The intense nineteenth-century focus on dressing the body (even the tiny body) and on observing the weekly variations of fashion through the widespread dissemination of fashion journals is not only indicative of the importance of appearance in the nineteenth century and the propensity for consumption and waste, but also of the growing focus on the child as future adult. In the mid- to late century, the valorisation of the child increased, with the first communion and college years becoming rites of passage that foreshadowed the future - the marriage of the girls, the career of the boys (Perrot et al. 172, 213-215, 229-233). In fashion journals, the increasingly ubiquitous use of the park - particularly in engravings depicting children's fashions - enhanced the spectacle and display of these new urban spaces. The public park is a space in which daily habit and chance encounter combine to create a socialised space for children, one in which they not only begin to observe and mimic their parents, but one in which they also begin to form their own decisions as to playmates and partners. The park is a space in which both suitable and undesirable (in the parents' eyes) playmates will cross, accidentally come into contact. The fact that the larger parks were also adult socialising spaces, furnished with not only benches and paths but with restaurants, bars, bandstands, cafés-concerts and open-air balls meant that here children were able to observe adults at play; of course this necessarily encompassed the observation of adults misbehaving and thus revealing the cases blanches - to cite Foucault (11) - of bourgeois discourse, the potential sites of a mapping of resistance to gender constructs.

\section{Gender Formation in the Park: Dress, Behaviour, Observation}

\section{Travel Guides and Fashion Journals}

Within the public park, there is not only a focus on the Self, through jouissance, consumption and display, but also on the Other, through spectacle and observation. The guignols, puppet shows, provide a specifically lilliputian — as the Guide Joanne observes - form of spectacle (205). Fashion journals repeatedly use the puppet show as setting for illustrations of children's clothing, thereby pointing to the popularity and respectability of such outdoor entertainment (plate 1). In a city whose new department stores and Opera House (completed in 1876) both catered to and celebrated the cults of spectacle and display, children found their own sized-down temples of these twin concepts within the public parks: the kiosk stuffed with edible and non-edible goodies and the puppet booth with its miniature stage upon which drama and murder were routinely played out. The fact that, as I discuss in detail elsewhere, there is such scrutiny in the public park 
makes the parading of one's children within such spaces a particularly loaded action due to the intense pressure on bourgeois women to be both fashionable and respectable, both desirable - within strict limits - and maternal. Fashion journals continually ran advice-charged pieces which attempted to help the bourgeois woman in the quandary facing her as to how to dress, both in terms of economy and style. What travel-guide writers note in relation to children in the parks is the overdressing - as Texier says, what a mother dares not wear herself, she tries out on her child: "Aussi, comme elles essayent sur leurs enfants tout ce qu'elles n'osent pas tenter sur elles-mêmes!" (306) Fashion journals moved with the times, from representations of nondescript garden scenes to settings clearly identifiable as public parks. The props of hoops and toys and the guignol featured regularly as did the new park architecture. By the mid-century the park had become the outdoor space in which the wealth and style of one's family could be exhibited on a daily basis, and as Texier suggests, mothers afraid to go overboard in their own toilette did not miss the opportunity for excess when dressing their children.

As a result, children become objects of adult curiosity in the park, of a focussed look that is both admiring and sizing up the child as a future representative of bourgeois society, and a present signifier of the successful parenting - or not - of the mother. Good behaviour is therefore essential in the public park. When less-than-perfect conduct appears, the focus returns to the mother, and her sense of duty is questioned. But as supervision of children was usual in the public space, it is the signifiers of dress that present the child to the onlooker and which make the child self-conscious of his or her body, and the way in which others -- other children and adults - respond to it. The intense contemporary focus on female appearance and desirability meant that girls, observing their mothers and older siblings' behaviour, were more likely to be aware of the importance of their appearance than were boys (although of course the discreetly and/or overtly soigné male could prove as equally persuasive a sartorial model for observant young men - as the sustained focus on dress, desire, pleasure and identity in Proust's $A$ la recherche du temps perdu illustrates - and for cross-dressing women, whether in reaction to or in emulation of such a modeliii). A moralistic tale in the literary Keepsake accompanying the 1861 Journal des Dames et messager des dames et des demoiselles presents an elegant mother, twenty-four years at most, anxious about appearances in the Tuileries. Her six-year-old daughter has just bought a small rose bush at the flower market in the Place de la Madeleine and the mother says they will not be able to walk through the Tuileries because they will look ridiculous:

Tout en parlant on avait descendu la rue Royale: l'intention de madame Hémery avait été de passer quelques instants sous les frais ombrages des Tuileries, mais le rosier qu'Emmeline tenait dans ses bras lui apparut comme un obstacle ridicule à cette promenade si chère aux enfants.

- Tu vois, dit-elle à Emmeline, nous n'allons pas pouvoir aller aux Tuileries. Ce serait ridicule de s'y promener avec un rosier dans tes 
bras: nous aurions l'air de pauvres gens qui n'ont pas chez eux de place pour mettre leurs fleurs au soleil. Il va falloir rentrer tout de suite à la maison. (125)

Charpentier's guide (1861), with reference to the Tuileries, explains the difference between the part of that garden called Petite-Provence and the Champs-Elysées:

L'animation sans doute n'est pas si grande qu'aux ChampsElysées, ou plutôt c'est un autre genre d'animation, moins bruyante et moins populaire par la nature même de ce lieu de promenade et du monde qui le hante. On n'y remarque point ce mélange incessant et cette éternelle confusion du peuple avec le grand monde, des divertissements plébéiens avec les plaisirs aristocratiques. Ce sont les enfants qui 1'égaient: on les rencontre partout, jouant aux soldats, poussant les cerceaux, lançant des toupies et des ballons, sautant à la corde, criant, pleurant, riant, frais et roses, vêtus des plus coquets habits et des couleurs les plus séduisantes. (28)

It is an image of happy affluence and a pleasure for the observer who is drawn to the children's clothing in what can only be described - even by nineteenth-century standards - as an unfortunate choice of adjectives: coquets, séduisantes. But more demonstrative of the roles - gender, class - observed and learned in the public park than any amount of description of children's clothing -- the focus upon it and the way in which it makes children behave - is the passage in Texier and Kæmpfen's Paris capitale du monde (1867) in which an embedded récit, purportedly by a doctor, describes behaviour and gender formation in the public park. It begins with the acknowledgement that as the nineteenth century progresses, speed can be said to characterise social interaction. Everyone is in a hurry to grow up, to progress, to succeed. Before analysing this passage, it is interesting to refer again to the earlier Tableau de Paris (1852-1853), in which Texier had already identified such strategies in the public park, albeit not necessarily asking the reader to focus on them in the way that the later text does.

Texier's Tableau de Paris, which offers as many visual as literary images of Paris in 1852 - it boasts 1500 engravings - identifies through observation and description of the Tuileries the kind of gender formation discussed above. The choice of adjective when describing the older children, the hardis garçons and sveltes petites filles is telling. While Petite-Provence is the reserve of mothers, nurses and babies, the older children have graduated to the Allée des Orangers, where they find themselves in a space in which young lovers smile and hopeful mothers bring their as-yet-unmarried daughters to find a match (plate 2). The older children are described as brimming with energy; the Allée des Orangers is where they let off steam: 
l'allée des Orangers offre de l'espace aux jeux des hardis garçons, des sveltes petites filles, aux cerceaux qu'on lance comme un cheval fougueux, à la balle qui bondit en tous sens, à la corde qu'on fait tourner avec adresse. (Texier 306)

\section{"Petite-Provence" and Kristeva's Theory of Child Development}

In Petite-Provence, gender is not yet an issue: although the girls are described as wearing white in honour of the Virgin Mary - preparing them for their future feminine duty - the little boys are described in the arms of their nursemaids. In this sense, Petite-Provence can be viewed as that pre-Law stage, of which Kristeva, following Lacan, speaks ${ }^{\text {iv: }}$ a period before issues of gender and duty have been taught by the parents, and during which the child is attached to the mother's or nursemaid's - in any case, the female — body. During this pre-Law stage, children are learning how to accomplish tasks through observing their elders, watching the interaction of their parents and siblings and household, and of course, noticing other children. In the Tuileries, the pre-Law stage has its own particular space (Petite-Provence) where there is je ne sais quelle tiédeur dans l'air, one that is sheltered - abrité - and described as an Eden of childhood.

The Eden metaphor is one that recurs in travel guides, seemingly as a throwaway statement, an acknowledgement of the paradisiacal nature of such parks. However, the image evidently always has the potential to suggest other interpretations. Adam and Eve left Eden when they became conscious of their bodies; so too do the petites plantes délicates, the fourmis, the créatures - all feminine nouns used to describe the infants in this pre-Law, attached-to-thefemale body- stage:

la Petite-Provence enferme dans son étroite enceinte toutes les fragiles créatures à peine échappées au biberon et au maillot. Là s'en viennent les petites filles vêtues de blanc en l'honneur de la sainte Vierge, les petits garçons que leurs bonnes portent sur le bras, et qui agitent dans leurs mains impatientes quelque pelle de bois ou quelque hochet à grelots. A chaque pas, on rencontre une de ces petites fourmis occupées à sa grande besogne, - le sable à creuser ou à amonceler, le ballon à atteindre, le cerceau à diriger. (306)

The boys, in the arms of their nursemaids, are already holding the tools of industry in their impatient little hands. The direct opposition of fragiles and hardis indicates the progress made by the boys in the Allée des Orangers. While all Parisians may acknowledge Petite-Provence as the Eden of their childhood, seemingly, while in it, the infants cannot wait to leave it for the action of the Allee des Orangers. 
Quoi! Vous avez douze ans et vous n'êtes pas encore de petites femmes parfaites! In the Tuileries with Texier and Kampfen: Paris, capitale du monde (1867)

Fifteen years later, Texier and Kæmpfen pick up on this image of gender formation in the park space as they describe the Tuileries once again, but this time not merely descriptively, reducing those observed to types, but homing in, through the introduction of a third party, the "doctor" - a character who is placed in the text to symbolise learned and rational reasoning - on one specific moment of observation, thereby sharpening the focus, making the text more vigorous in seeming more precise:

L'autre jour je traversais le jardin des Tuileries: une petite fille sautait à la corde:

- Plus vite, plus vite! disait-elle à ses compagnons qui tournaient la corde: "Plus vite, plus vite!" le mot de la petite fille est le mot de ce temps-ci. On ne vit plus, on court la vie... (Texier and Kæmpfen 24)

On voit encore quelques petites filles qui jouent à la poupée et quelques petits garçons qui jouent aux soldats. Fi! quelles mœurs arriérées! Vite, à la bourse aux timbres-poste, jeunes messieurs! Préparez-vous pour l'autre, pour la grande, pour celle que vos papas vous montrent d'un geste sublime dans l'avenir radieux; apprenez les secrets de la prime et les ressources du report... [...] Et vous, mesdemoiselles, étudiez la Mode illustrée et la Gazette rose, lisez les articles de madame la vicomtesse de $\mathrm{X}$... et de madame la marquise de $Z$..., et, passant de la théorie à la pratique, imitez vos mamans. Quoi! vous avez douze ans, et vous n'êtes pas encore de petites femmes parfaites; vos frères ont treize ans, et ils ne sont pas encore de parfaits petits hommes! N'avez-vous pas honte, messieurs et mesdemoiselles? Regardez autour de vous, voyez vos contemporains et vos contemporaines: leurs pères et leurs mères en petit! Suivez ce charmant exemple. Laissez là les soldats et les poupées. Le siècle supprime les enfants, et les enfants sont tout fiers d'être supprimés. (29-30)

The tone is heavily ironic - the "editors" disclaim responsibility by asking the reader to decide whether or not Doctor*** is right in the Avant-Propos:

Nous livrons à la publicité une mince partie d'un volumineux manuscrit qui nous a été legué par un médecin, le docteur***. Spectateur curieux, observateur attentif des choses de son temps, il a eu la fantaisie d'écrire ce qu'il voyait et ce qu'il entendait. Le docteur raconte-t-il bien? Juge-t-il sainement? Ces feuillets l'apprendront à qui voudra le savoir. (Avant-propos) 
The editors play on the possible registers of the text - the "doctor" is humoured when they state that he had la fantaisie d'écrire, and when they ask if his judgement is healthy: juge-t-il sainement? But they nevertheless launch the text to the public, so one draws one's own conclusion. The pretence of verisimilitude, of the using of actual textual fragments in a new presentation is a literary device frequently used in eighteenth and nineteenth-century travel guides and novels to claim authenticity for a text. In this case, the supposed doctor's initial observation of the girls in the Tuileries is developed and takes an exaggerated form in the hyperbolic second passage to urge the reader of the encroachment of adulthood on childhood all the while carrying him along with the motif of speed and progress. The accumulative use of apostrophe and of the imperative are in themselves tools of persuasion. By the last sentence, irony falling heavily all around, the doctor is saying one thing and like Jonathan Swift in his Proposal, intending quite another.

\section{Renoir's La Promenade [Mother and Children] (c. 1874)}

Such an image of the encroachment of adulthood on childhood could be said to describe Renoir's La Promenade [Mother and children], in which the two girls, dressed as little women, are being presented by their elegant mother/nanny to an unseen viewer in a park setting. The title of the painting is problematic. Acquired by Henry Clay Frick in 1914, it previously belonged to Potter Palmer's celebrated collection of Impressionist paintings in Chicago (Ryskamp et al. n.p.). The available documentation of Potter Palmer's collection is the catalogue for the sale of his estate at his death in 1944. Palmer possibly acquired the painting from DurandRuel but it does not figure in the list of paintings shown either by Durand-Ruel or by Renoir himself in public exhibitions prior to the twentieth century. The painting is called Mother and Children by The Frick Collection; this seems to have always been the case: in 1928 it appeared in George Harvey's biography of Frick under this title; Harvey dates the acquisition to 1918 (331-343). The catalogue Paintings from the Frick Collection (1990) which dates the acquisition to 1914 acknowledges that the subjects of the painting (following "a plausible tradition") were "two daughters of a prosperous Parisian family of Italian origin," accompanied not by their mother but by "their nurse," "whom Renoir encountered in the park adjoining the church of La Trinité, not far from his studio" (n.p.). While the painting, following the Frick tradition, is generally known as Mother and Children, Elda Fezzi's 1985 catalogue raisonné calls it La Jeune mère (Promenade) (154). Christopher Prendergast calls it La Promenade: femme et enfants although he does not discuss his reasons for so doing (174-175). Accepting the Frick's "plausible tradition" of the identification of the location and the subjects of the painting, the viewer has to question whether Renoir willingly played on the fantasy of the respectable woman wearing her hair down (visible, not hidden, sign of female sexuality). In terms of dress, the painting seems not to represent a mother and her children but a nanny and her charges: no respectable woman, certainly not one as wealthy as the one represented in the painting, would have worn her hair loose in public in the 1870s. She could of course be a courtesan (Nana enjoyed displaying her son Louiset at the races') but it is unlikely: her body language is 
more that of a nanny or mother. However, the woman clearly resembles the two girls, as will be further discussed below. The dating of the painting is equally controversial: Fezzi puts it at c. 1874, as does Prendergast. The Frick Collection, likening it to the later portrait of Mme Charpentier and her Children (1878), which belongs to the neighbouring Metropolitan Museum, dates it c. 1876-1878. For the moment, the painting will be analysed as La Promenade, and the question of its title will remain open-ended.

In La Promenade, the attention on the young girls' dress is emphasised by the richness of the colours and textures used by Renoir to create a sensuous image that appeals to the spectator's sense of visual and tactile pleasure. The two girls are being initiated into the concepts of spectacle and display in the public park, and the importance of appearing to carry the signs of their good behaviour and potential value (the future dowry for the calculating onlooker). The main focus on pink, brown, and orange hues contrasts with the green of the girls' outfits, but manages to associate all three women with nature in this autumnal scene. In the background there are more women and children, but they are made less elegant, painted in blues, black, and white, a patch of contrasting light and shade in the top right-hand corner of the painting, to provide the perspective of the path leading back into the park, and confirm the setting as that of a public park. In the foreground, the colours are sensual and both warm (the pinks, browns and oranges) and cool (the iridescent green of the girls' outfits), relaxing and stimulating the viewer/spectator. One is reminded of Paul de Kock and Alphonse Karr's remarks in the 1867 Paris Guide:

Des femmes et des fleurs. Ah! ... (Kock 1284)

C'est quelque chose aussi de penser qu'on verra une belle jeune fille regarder et admirer des fleurs... (Karr 1227)

Renoir's painting thus sets up a spéculaire fascinant ${ }^{\mathrm{vi}}$ for the observer in the park (located at the bottom right hand side of the canvas, at the bend in the path) and the viewer of the painting who equally well positions him- or herself at this point. These young girls greet the viewer with open looks, the younger child curious but not wary, the elder quite at ease, with the hint of a smile; both aware of their physical presence: their princess-like outfits contrasting with the plainer dress of the women and children in the background of the painting. Like Renoir's Jeune fille $a$ l'ombrelle (1883) these girls are not yet conscious of a negativity surrounding the phallocentric gaze and are uninhibited by the observer. It is only when the young woman is aware of patriarchal requirements, and her status as marriageable commodity and future mother, that the sense of unrestricted playfulness, ease in her body and its relation to a viewer, is lost. Simone de Beauvoir analyses the changing relationship of the young woman to her body in Le Deuxième sexe (1949). Renoir did not problematise the relationship of the female subject to her body or her conventional roles as object of desire and mother. The fact that he did not do so reflects his personal views which were those of the majority of contemporary 
men (see Herbert and Monneret). When similar subjects are represented by Morisot, Cassatt and Manet, a different attitude is apparent, one that problematises the phallocentric viewing of the female body and/or the relationship of the woman to her body: that is, the woman not as Other, defined by a lack, but as Self. Such paintings successfully critique the dominant discourse, as the above analysis demonstrates. Renoir's La Promenade [Mother and Children] will be further below, in comparison to Morisot's images of young women in the Bois de Boulogne.

\section{Zola's Le Ventre de Paris (1873)}

For children the park space is a first taste of independence from the family unit. In Zola's Le Ventre de Paris (1873) Muche and Pauline's visit to the park is about freedom from parental control. For Pauline, it is a case of escaping from the bourgeois constraints that make her fear dirtying her new dress, but ultimately she finds that freedom is not exactly what she needs to make her happy. In Le Ventre de Paris Zola places a pivotal scene in terms of the plot dynamic in the park. For the preceding two-thirds of the novel, Florent's true identity has been hidden, and it has stumped the other characters, notably local busybody Mlle Saget. Zola makes the park, the Square des Innocents the place in which Florent's cover is blown by his six-year-old niece Pauline. In this novel, Zola takes the travel-guide tableau discussed above - the babies blonds et roses, etc. — and inverts it. Gone are the beautifully dressed children behaving themselves; instead the tableau is composed of children in rags, with runny noses, described as vermin, playing with broken toys, crying and biting each other. In terms of the settings used in the novel the park is an alternative space, one which offers a potential escape from the insular world of Les Halles, Paris's central market, reconstructed after 1851, where the novel is almost entirely set, in 1858-1859. Haussmann notes in his Mémoires that the Square des Innocents was only constructed vers 1859, après l'achèvement complet des Halles (vol III, 243); so Zola is playing with the timescale as he sometimes does to make everything fit into his fictional chronology. The park certainly seems to be well-established by the time this episode appears - Muche spends most afternoons there, Mlle Saget comes for her daily gossip.

Muche and Pauline, seven- and six-years-old respectively, whose mothers have fallen out and forbidden them to play together, go to the park and cause the kind of havoc Alphand and André fear, throwing sand at each other, breaking branches off bushes, digging holes in a flower bed and planting their own stick trees in them, then running outside the square to scoop up water in their hands to bring back and water their new garden. After this they are of course filthy and wet. It does not matter much to Muche, whose clothes were torn to begin with, but the passage begins with Pauline in a beautiful new dress, looking for admirers in front of her parents' shop. Zola details her outfit, so as to make the subsequent destruction of it all the more comic:

Elle se tenait toute droite, devant la boutique, bien sage, les lèvres pincées par cette moue grave d'une petite femme de six ans qui 
craint de se salir. Ses jupes, très courtes, très empesées, bouffaient comme des jupes de danseuse, montrant ses bas blancs bien tirés, ses bottines vernies, d'un bleu d'azur; tandis que son grand tablier, qui la décolletait, avait, aux épaules, un étroit volant brodé, d'où ses bras, adorables d'enfance, sortaient nus et roses. Elle portait des boutons de turquoise aux oreilles, une jeannette au cou, un ruban de velours bleu dans les cheveux, très bien peignée, avec l'air gras et tendre de sa mère, la grâce parisienne d'une poupée neuve. (815)

Pauline would not be out of place, in winter gear, in Renoir's La Promenade or in a fashion-plate engraving and certainly fits the Tuileries constant. She is rose, bien sage, worried about getting dirty and her boots are polished. She even has la grâce parisienne d'une poupée neuve. However, her time in the park, unsupervised and rowdy, makes her an altogether different sight, one that shocks her mother Lisa but delights Mlle Saget who brings Pauline home, tout égayée par cette scène. Pauline has never been to the square before. The reader learns later on that her parents occasionally go to the Bois de Boulogne, and this reflects their social aspirations as respectable shop-keepers. The Square des Innocents is probably not a desirable place in their eyes. The travel guides make it clear that there was a kind of park hierarchy, which depended on the area in which a park was located. The Square des Innocents does not provide the sort of respectable space for parading and spectacle of the kind to be found in the Tuileries. Lisa's horror is all the more great then, when she hears that her daughter has been misbehaving in public. Outings to the parks had to be planned and supervised for good behaviour and display of affluence to shine during them:

Lisa ne trouvait pas une parole. Elle ne savait par quel bout prendre sa fille, tant les bottines boueuses, les bas tachés, les jupes déchirées, les mains et la figure noircies, la dégoûtaient. Le velours bleu, les boutons d'oreille, la jeannette, disparaissaient sous une couche de crasse. Mais ce qui acheva de l'exaspérer, ce furent les poches pleines de terre. Elle se pencha, les vida, sans respect pour le dallage blanc et rose de la boutique. Puis, elle ne put prononcer qu'un mot, elle entraîna Pauline, en disant:

"Venez ordure." (821)

At the beginning of the passage, Muche sees Pauline and goes over to her, wanti$\mathrm{ng}$ to touch la jolie robe à raies bleues. With a mixing of register — that of childish behaviour and language and the language of adult courtship - Zola makes the two children interact and brings them to the park, where they will be found by the malicious gossip Mlle Saget who in pretending to cajole the now crying Pauline and telling her she will bring her home, bullies her into repeating what her parents say about Florent, supposedly her mother's cousin and whom Mlle Saget suspects of being a dangerous impostor. But in addition to the structural motor behind the 
park scene - the essential narrative development - the scene offers an image of children interacting both instinctively and trying to emulate their elders. Muche leads Pauline into the square, a place she has never been. Zola has already alerted the reader that Muche devait nourrir l'idée mauvaise de salir Pauline. During this passage Zola uses the words and gestures of adult courtship to suggest the instinctive flirtation between the two. Muche has a sou in his pocket and says he will buy her a cornet of sweets:

Alors, il lui prit le bras, il l'emmena, sans qu'elle résistât.

[...]

Ils entrèrent dans le square. C'était là sans doute que le petit Muche rêvait de conduire sa conquête. Il lui fit les honneurs du square, comme d'un domaine à lui, très agréables, où il galopinait pendant des après-midi entières. Jamais Pauline n'était allée si loin; elle aurait sangloté comme une demoiselle enlevée, si elle n'avait pas eu du sucre dans ses poches. (816-817)

They go and look at the Jean Goujon fountain with its naked nymphs, already thinking of forbidden things:

rêvant certainement de traverser la pelouse centrale, ou de se glisser sous les massifs de houx et de rhododendrons, dans la platebande longeant la grille du square. (817)

Their games begin. Muche suggests they throw sand at each other. Pauline était séduite. Muche is delighted to see Pauline getting dirty, but she's not dirty enough yet, so Muche suggests they make their own garden and plant their own trees. Pauline is pleine d'admiration.

Alors, comme le gardien du square n'était pas là, il lui fit creuser des trous dans une plate-bande. Elle était à genoux, au beau milieu de la terre molle, s'allongeant sur le ventre, enfonçant jusqu'aux coudes ses adorables bras nus. Lui, cherchait des bouts de bois, cassait des branches. C'était des arbres du jardin qu'il plantait dans les trous de Pauline. Seulement, il ne trouvait jamais les trous assez profonds, il la traitait en mauvais ouvrier, avec des rudesses de patron. (817)

Muche goes from being galant to bossy to possessive, copying different models of adult behaviour he has observed (the lover, the boss, the husband). After they have watered their trees, he gets Pauline to sit under a rhododendron bush with him "Muche la trouva très bien, quand elle fut très sale. [...] Il lui avait pris la main, en l'appelant sa petite femme" (818) - and tells her not to tell her mother otherwise he will come and pull her hair whenever he passes her house. 
Pauline répondait toujours oui. Lui, par dernière galanterie, lui remplissait de terre les deux poches de son tablier. Il la serrait de près, cherchant maintenant à lui faire du mal, par une cruauté de gamin. Mais elle n'avait plus de sucre, elle ne jouait plus, et elle devenait inquiète. Comme il s'était mis à la pincer, elle pleura en disant qu'elle voulait s'en aller. Cela égaya beaucoup Muche, qui se montra cavalier; il la menaça de ne pas la reconduire chez ses parents. La petite, tout à fait terrifiée, poussait des soupirs étouffés, comme une belle à la merci d'un séducteur, au fond d'une auberge inconnue. Il aurait certainement fini par la battre, pour la faire taire, lorsqu'une voix aigre, la voix de Mlle Saget, s'écria à côté d'eux: «Mais, Dieu me pardonne! C'est Pauline... Veux-tu bien la laisser tranquille, méchant vaurien! » (818)

The Square des Innocents, in Zola's naturalistic description, reflects the popular aspect of the quarter. The passage displays, however, a heightened realism, a carefully-constructed and for that, poetic, image of viciousness and poverty in the park space. Zola combines the heightened naturalistic setting with the comic enumeration of the children's antics and the artifice of plot development. In the park, Muche and Pauline do not perform constructive tasks as do the children observed and written about in the travel guides: skipping, playing with hoops, games of soldiers. They are destructive: digging holes in flowerbeds, breaking branches - and it ends in tears and a threat of violence. Pauline will not stop crying and Muche is on the point of hitting her when Mlle Saget finds them. In the travel guides discussed above, the important signifiers in the park were identified as behaviour and dress, revealing family respectability and good upbringing: essential to those who had bourgeois aspirations, as did most shop-keepers for whom the Empire had bettered the lot.

Zola, in depicting this working-class square, does so in a way that no travel guide does, creating a constant that is not sunny and cheery but depressing: children in rags, crying, fighting. Pauline starts out in a beautifully clean new dress. The theme of cleanliness is recurrent, almost obsessional in Lisa's household. The park is a space of spectacle and display, but one that would mortify Pauline's parents who are well-off shop-keepers as opposed to Muche's mother who at this point in the narrative is a fishmonger in the Halles, and who is well aware of the sort of games he gets up to. The spectacle in the square of Muche and Pauline running around, getting progressively more dirty and wet, is amusing for the reader as he follows Zola's detailed description of the children's actions, words and thoughts, and it is a display of the kind of bad behaviour that the park creators feared from the outset, as I discuss in detail elsewhere. The complicity between the narrator and the reader breaks the "reality" of the text, the comedy is an element of artifice that combines with the heightened naturalistic description to reveal authorial intention. 


\section{Morisot and the Bois de Boulogne (1879-1893)}

One can read the park as site for child development - the performing of tasks or games, observation of elders, social interaction and the beginning of bodily consciousness - in Berthe Morisot's paintings of the Bois de Boulogne from the late 1870 s to the $1890 \mathrm{~s}$. Frequently Morisot painted children and young women; one of her favourite models was her daughter Julie, born in 1878. This choice of subject-matter led critics for many years to assess her contribution to art history as an insipid or saccarine representation of domesticity, but in the last two decades of the twentieth century the efforts of art historians such as Linda Nochlin and Griselda Pollock challenged such readings by claiming them representative of the phallocentric structures charged with the task of critical assessment. When female critics first looked at these paintings, alternative analyses were forthcoming, and later critics such as Christopher Prendergast have acknowledged the ambiguities discussed by Nochlin and Pollock with reference to such images as Jour d'été (1879).

The dumbing-down criticism took away the potential power of images by Morisot and Mary Cassatt, whose work was also read as unchallenging for many years. The challenge lies in their focus on the expression of women and children and particularly female adolescents who are placed in surroundings where nineteenth-century social exposure is unnerving for them. The public images present a different vision of nineteenth-century society, one that makes women conscious of their appearance - their body and dress - and their achievement of the required benchmarks of femininity: elegance and motherliness. Images of a private interior are necessarily different, and do not expose the young woman to physical criticism, as can be evinced from the unselfconscious poses of Morisot's bathroom and toilette scenes.

It is the requirements of the public sphere, into which they are being initiated, and once out, are having to negotiate, that creates ambiguities and tensions in images of young women painted by Morisot and Cassatt, such as Le Corsage noir (1878), in which an uneasy débutante, conscious of her appearance, is made doubly so for the spectator who is aware of the significance of the painting's title, and Cassatt's La Loge in which young women hide behind fans and look awkward in their newly-bared shoulders (1882). Quite different are such images from Renoir's seemingly breathless girl leaning forward in her box to involve herself in the action (La Première Sortie, 1875-1876). But it was necessary for a nineteenthcentury man to question gender constructions and roles before portraying such images: Manet does this repeatedly, but Renoir, a man uncritical of gender roles of his time, paints what the male viewer expects to see: breathless, excited, easily influenced young women, or content mothers, or nudes, waiting to receive their orders. So, in the image discussed above, La Promenade [Mother and Children], Renoir presents the spectator with the image of the mother/nanny, young, richly dressed in a fur-trimmed cloak, drawn up at the back to reveal and emphasise the bustle, presenting her two similarly dressed young charges, in green satin or watermarked silk and white fur as opposed to their mother/nanny's black velvet and brown fur, but with the same burnished hair falling down their backs. If 
Renoir meant the female subject to be a mother, he presents the viewer with a fantasy of the respectable woman's hair - symbolising her sexuality - left loose. If one accepts the title Mother and Children, one still has to admit that it is an unusual image in that the mother is wearing her hair down; her respectability guaranteed by the opulence of her dress? Or is she a courtesan in a rare moment of maternal display of her children? Less likely, perhaps, although Zola's Nana dressed Louiset up like a doll and displayed him in her carriage at Longchamp. If the viewer reads the woman as nanny, it is still evident that Renoir painted the three female bodies to resemble each other. Having noted the above, in the following analysis, "mother" may be replaced by "nanny." The eyes of all three, dark, unchallenging, and their lips, pink and almost smiling, are set in porcelain-like complexions, with the merest hint of blush, which emphasise their doll-like appearance. This is further emphasised by the doll carried by the elder of the two girls. It is clasped in her two interlocked hands, as though she knew the importance of looking after this simulacrum of her future children, but it is also lying back, inert, head facing up, as opposed to the focussed gaze of the three young women off canvas left, on the person to whom they are being presented, and by extension, the spectator. The younger daughter's hands are clasped in a muff, the mother's right hand gently pushing the younger daughter on, her left hand holding her skirt - probably so as the elder daughter won't step on it - we see the hint of a white underskirt below, the movement emphasised by the sweep of the mother's skirt and the girls' white boots and stockings moving ahead. They are all being presented to the viewer, and are suitably packaged: richly, elegant in their hats, the mother tied up with a bow round her neck.

It both reflects and contrasts to the images that Morisot produces of women and children in the park. The elegant dress is similar, the attitude of the painted subject different. In Renoir's image, everything conspires to make the viewer want to touch the women. The textures are sensual and visually appealing, reflecting the attitude of the subjects, who are open to contact. It reflects the travel-guide description of children in sensual colours. In Morisot's images, there is often a sense, reinforced by a technical effort to leave the image unfinished or difficult to read, with brushstrokes suggesting rather than defining the subjects, particularly their dress, constituting a distancing technique, both from the intimated third presence in the painting and the spectator. This indication of an ambiguity, a tension in relationships, of the consciousness of being an object of desire or on display, a marriageable commodity and future reproducer, is present in such images as Morisot's Jour d'été (plate 9), Le Corsage noir (1878), Jeune Femme au bal (1879) and Femme assise au bois de Boulogne (1885) and Cassatt's Portrait de Lydia (1879). They suggest a pre-suffragette disinclination to fit the gendered mould of nineteenth-century femininity, and to smile when flattered and flirted with.

In these images, hands are often clasped in a protective gesture that closes the body from the viewer, and parasols are laid across the lap to both cover the body and act as a protective device, such as in Jour d'été, but also in Femme assise au bois de Boulogne, as I discuss elsewhere. In Bois de Boulogne, 1893 (plate 10), 
Morisot presents a disgruntled, fifteen-year-old Julie, whose features, though indistinct, are not those of a smiling young woman: her mouth is a straight line, her eyes are small and half-closed, almost teary. One hand on her hip, her dog jumping up to get her attention on the other side. The setting is an open space in the Bois, where almost-abstract figures signify the action: a horse's head, cut off by the frame, on the right of the canvas, a dark patch suggesting a rider, a woman in brown, walking, a nurse with a toddler, a carriage sketched in, and Julie standing in the midst of this, in a picture hat, her waist cinched in with a black belt, and her hair falling over her shoulders. In this image, the viewer has to decipher the painted signs that do not beckon him into the picture, but isolate him from this painted scene of almost abstract touches, where the grass is long and made up of green, blue, yellow and white brushstrokes, where the trees are hinted at or made slabs of darker colour, as in the foreground's slim trunks. It is for example difficult to make out the central section in the background, behind the woman in brown, although it is likely that the red and mauve patch is a boat and the figure to its right someone, torso visible, in another boat on the lake. But all of this indecipherability puts the viewer into a different position compared with the Renoir discussed above. Instead of being welcomed into the image, confirming nineteenth-century expectations, this painting from Morisot confounds such expectations. Here is a girl, dressed desirably, but who is not willing to be read as such. The viewer, like the orange dog with its black collar, has to be trained to access the intention of the painted subject, which remains unknowable because of the lack of definition in her features and the pose which is both provocative (hand on hip) and distanced (she is set back into the scene).

In creating such images, Morisot contributes to the iconography of the spectacularised female body in the nineteenth-century Parisian park, but also sets up a distance, a restraint. Instead of the appealing and inviting images for viewer contact presented by Renoir for example, she presents a tension that challenges the viewer by not allowing him to move forward without hesitation and confront the painted subject. It is the same dynamic that works in Cassatt's Portrait de Lydia, where the body language and the abstract touches warn off the viewer, make him stop and decide, question his own intentions while deciphering those of the painted subject, who, while present and correct in a public space, may not be a willing object of desire.

It is clear then, that the public space, and particularly the park - where children begin to observe others and interact with them, where they begin to learn how important the body and appearance are in social relations, how to behave and emulate their elders, and perhaps even to distance themselves from, while remaining within bourgeois convention - is an essential space for the formation and observation of the petite fille, prototype of the bourgeois icon of female respectability and elegance and inevitably, to the eyes of contemporary phallocentric society, the index of male material success. By the time the petite fille had learnt her feminine duty and come out, she may also have learnt how to subvert contemporary gender definitions; this was largely the case, and largely a fear unvoiced by bourgeois society, which preferred to demonise the "dishonest" prostitute than analyse too closely the behaviour of its maternal icons. 


\section{Notes}

i In nineteenth-century Paris, the dominant discourse was "phallocentric," that is, centred on the Phallus, the Lacanian signifier of sexual difference which guarantees the patriarchal structure of the Symbolic order (of language, laws, social processes and institutions). By "discourse" I mean the written and unwritten practices and codes which structure social and sexual relations, cultural practices and institutions in a given society. Retrospectively viewed, nineteenth-century female experience was defined in relation to phallocentricity. In the twentieth century, from Simone de Beauvoir's positing of woman as "Other" in Le Deuxieme sexe (1949), feminist critical activity has focussed on examining female "otherness" within phallocentric culture. Subsequent to radical feminist (second-wave) politics of the late 1960s, the feminist critical activity of the 1970s focussed on phallocentricity, the male gaze and its objectivisation of women. However, as later criticism developed more complex theories of the male gaze and the female subject, particularly within film studies, feminist critics began to question earlier critical assumptions about the male gaze. In Male Subjectivity at the Margins (1992) Kaja Silverman argues that the dominant discourse, what she calls the dominant "fiction" of conventional masculinity is fragile, only sustainable by women co-operating with that dominant fiction: men live in the shadow of the symbolic Phallus which can always perform. Such an acknowledgement alters the early feminist critical perception of the nineteenth century as one in which women were powerless, subject of the male gaze, and men all powerful, masters of the gaze. Women could turn away, break the gaze and the phallocentric fantasy/fallacy, and little girls learnt by example.

ii Important for my understanding of late-nineteenth-century female experience (experience defined in terms of a lack, in terms of its Otherness vis-à-vis contemporary phallocentricity) are Cixous's "Laugh of the Medusa" with its focus on female pleasure and Kristeva's "Motherhood according to Giovanni Bellini" with its focus on jouissance.

iii For the purposes of this essay, I limit my discussion to the model of "honest" femininity. For a broader discussion of gender, dress and identity, see Furlong 2001.

iv Kristeva demonstrates, after Lacan, in various texts and in varying styles, the way in which the infant develops, recognising itself as a separate entity from its mother at the "mirror stage" and eventually succumbing to the Law of the father in order to progress as a social being. This child development constitutes the adoption of the dominant discourse and the representations of that discourse, particularly true in the case of the nineteenth century when open subversion of that discourse was rare. This development stifles the semiotic impulse (unformulated language, sounds, sensations) in the infant who is linked to the mother's body, in order to constitute a symbolic subject, one who recognises the Law of the father. Kristeva's doctoral thesis, La Révolution du langage poétique (1974) explores ways in which writers can attempt to revive the semiotic impulse and articulate it within a symbolic construct, the text prepared for publication. 
Kristeva's formulation of the conflicting yet symbiotic semiotic and symbolic drives can be said to characterise nineteenth-century gender relations. Women are viewed as the unformed weaker sex, "femininity" is a construct of all that "masculinity" is not (that is, not strong, not rational, not active). See Kristeva 1974, 1980, 1994.

" See Emile Zola, Nana.

vi In "Fantasme et cinéma," part of the 1995-1996 lecture series published as Pouvoirs et limites de la psychanalyse, Kristeva posits literature and art as the ideal space for the formulation of fantasy. The notions of the look, its identification of an object and the potential fantasy engendered by that object, are the basis of the lecture. Although Kristeva's analysis is in the context of film, it is also applicable elsewhere. When we view an object, we look at it and identify it. This, in Kristeva's terms, is the regard identifiant. This look invites la spéculation dite intellectuelle which establishes one identity as opposed to another, "me" socialise et rassure les autres sur mes bonnes intentions. But from the moment when the look ceases to be merely identifying or an invitation to intellectual speculation, it becomes [le] spéculaire fascinant. She introduces the concept of the spéculaire, ce lieu de notre vie psychique où l'imagination se laisse commander par le fantasme. If we take Kristeva's three elements (fantasy as "representation"/literature and art as prime site for the formulation of fantasy/the spéculaire) and conflate them we are able to create a frame for the analysis of nineteenth-century painting and writing which presuppose a reader/viewer who is, one, attuned to the dominant discourse and two in a psychological state conducive to the realisation of a fantasy. Kristeva insists that ce que je vois n'a rien à voir avec le spéculaire qui me fascine (Kristeva 1997, 135-6).

\section{Works Cited}

Baudelaire, Charles. Le Peintre de la vie moderne. In CEuvres complètes II. Paris: Gallimard, La Pléiade, 1976.

Charpentier. Paris dans sa splendeur: monuments, vues, scènes historiques, descriptions et histoire. 3 vols. Paris: Ed. Charpentier, 1861.

Cixous, Hélène. "The Laugh of the Medusa" (1976). New French Feminisms: An Anthology. Eds. Elaine Marks and Isabelle de Courtivron. New York-London: Harvester Wheatsheaf, 1981. 245-264.

Fezzi, Elda, Simone Darses and Jacqueline Henry. Tout l'ouvre peint de Renoir: période impressionniste 1869-1883. Paris: Flammarion, 1985.

Foucault, Michel. Les Mots et les choses. Une archéologie des sciences humaines. Paris: Gallimard, 1966.

Furlong, Sinéad Helena. Women in the Parks of Paris: Painting and Writing the Female Body, 1848-1900. Trinity College Dublin, PhD Thesis, 2001.

Harvey, George. "An Art Collector". Henry Clay Frick: The Man. New York-London: Charles Scribner's Sons, 1928. 331-343. 
Herbert, Robert L. Impressionism: Art, Leisure and Parisian Society. New Haven-London: Yale University Press, 1991 [1988].

Joanne, Adolphe. Paris illustré en 1870: guide de l'étranger et du parisien. Paris: Hachette, 1871.

Karr, Alphonse. « Les Fleurs à Paris ». In Paris Guide, par les principaux écrivains et artistes de la France, préface de Victor Hugo, vol. II. Paris: A. Lacroix, Verbœckhoven et Cie, 1867.

Kock, Paul de. « Les Boulevards de la Porte Saint-Martin à la Bastille ». In Paris Guide, par les principaux écrivains et artistes de la France, préface de Victor Hugo, vol. II. Paris: A. Lacroix, Verbœckhoven et Cie, 1867.

Kristeva, Julia. La Révolution du langage poétique: l'avant-garde à la fin du XIXe siècle; Lautréamont et Mallarmé. Paris: Seuil, 1974.

— "Motherhood according to Giovanni Bellini". In Desire in Language: $A$ Semiotic Approach to Literature and Art. Eds. Leon S. Roudiez, Thomas Gora and Alice Jardine. New York, Columbia University Press, 1980. 237-270.

_ "From One Identity to an Other". In Desire in Language: A Semiotic Approach to Literature and Art. Eds. Leon S. Roudiez, Thomas Gora and Alice Jardine. New York, Columbia University Press, 1980. 124-147.

- and Susan Sellers. "A Question of Subjectivity - an Interview”. In Modern Literary Theory: A Reader. Eds. Philip Rice and Patricia Waugh. London-New York: Edward Arnold, 1994. 128-134.

— La Révolte intime (Pouvoirs et limites de la psychanalyse II). Paris: Fayard, 1997.

Le Journal des dames et messager des dames et des demoiselles, Paris, 1861.

Monneret, Sophie. Renoir. Paris: Editions du Chêne, 1989.

Nochlin, Linda. "Morisot's Wet Nurse: the Construction of Work and Leisure in Impressionist Painting". In Women, Art and Power and Other Essays. London: Thames and Hudson, 1994 [1989]. 37-49.

Parke-Bernet Galleries. Distinguished Paintings by Modern Artists and Works by Nineteenth-Century Painters, including Renoir, Manet, Van Gogh, Gauguin... all from private owners, including the estate of the late Potter Palmer... [Auction in New York, Parke-Bernet Galleries, 16 March 1944; catalogue]. New York: ParkeBernet Galleries, 1944.

Perrot, Michelle et al. Histoire de la vie privée IV: De la Révolution à la Grande Guerre. Paris: Seuil, 1999 [1987].

Pollock, Griselda. "Modernity and the Spaces of Femininity". In Vision and Difference; Femininity, Feminism and the Histories of Art, London-New York: Routledge, 1994 [1988]. 50-90.

Prendergast, Christopher. Paris and the Nineteenth Century. Oxford UK-Cambridge USA: Blackwell, 1995 [1992].

Ryskamp, Charles et al. Paintings from The Frick Collection. New York: Harry N. Abrams/The Frick Collection, 1990.

- The Frick Collection. A Guide to Works of Art on Exhibition. New York: The Frick Collection, 1999 (10th ed).

Texier, Edmond. Tableau de Paris, ouvrage illustré de quinze cents gravures..., vol. 1. Paris: Paulin et Le Chevalier, 1852-1853. 